\title{
ВЛИЯНИЕ ПРЕПАРАТА КОСТНОМОЗГОВОГО ПРОИСХОЖДЕНИЯ НА ПОКАЗАТЕЛИ КРОВИ ЛАБОРАТОРНЫХ ЖИВОТНЫХ
}

\section{P.V. Punina}

\section{THE EFFECT OF THE DRUG FROM BONE MARROW ON THE INDICATORS OF BLOOD OF LABORATORY ANIMALS}

Пунина Полина Викторовна - асп. кафр. ветеринарно-санитарной экспертизы, эпизоотологии и микробилогии Дальневосточного государственного аграрного университета, г. Благовещенск. E-mail: evsova@gmail.com

Проведено исследование с иелью установления воздействия белкового препарата, полученного из клеток костного мозга крупного рогатого скота, на морфологические и биохимические показатели крови лабораторных животных (белых мышей). Получение препарата проводили в соответствии с рекомендациями Н.М. Мандро и Т.В. Федоренко (2016) с модернизацией метода. Для проведения опыта сформированы 3 опытные и 1 контрольная группы по 21 голове в каждой. Подопытным группам однократно вводили 0,1 \% раствор белкового препарата в дозировках 0,01; 0,02; 0,03 мл подкожно. Контрольной группе в тех же дозах вводили подкожно 0,9 \% раствор $\mathrm{NaCl}$. Отбор проб крови осуществляли на 7-й, 14-й и 21-й дни после введения препарата. По результатам опыта выявлено достоверное увеличение морфологических и биохимических показателей крови подопытных групп лабораторных животных. Во второй опытной групnе на 7-й день проведения эксперимента отмечено увеличение эритроцитов на 6,07 \%, лейкоцитов - на 33,17 \%, моноцитов - на 86,32 \%, лимфоцитов - на 14,42\%. Достоверное увеличение биохимических показателей в данной опьтной группе на 7-й день эксперимента составило: количество общего белка - на $42,13 \%$, альбуминов - на $34,22 \%$,

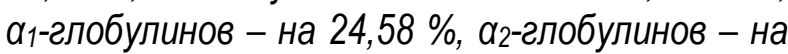
23,89 \% и ү-глобулинов - на 99,18 \% по сравнению с данными животных контрольной группы.
Punina Polina Victorovna - Post-Graduate Student, Chair of Veterinary and Sanitary Examination, Epizootology and Microbiology, Far Eastern State Agrarian University, Blagoveshchensk.

E-mail: evsova@gmail.com

При этом указанные показатели крови остаются в пределах физиологической нормы.

Ключевые слова: препараты костного мозга, лабораторные животные, лейкоцитарная формула, белковые фрракции сыворотки крови.

The research was made for the purpose of the establishment of the influence of proteinaceous preparation received from cells of marrow of cattle on morphological and biochemical indicators of blood of laboratory animals (white mice) was conducted. Receiving the preparation was carried out according to N.M. Mandro and T.V. Fedorenko's recommendations (2016) with modernization of the method. For carrying out the experiment 3 experimental and 1 control groups with 21 heads in each were created. To experimental groups once $0.1 \%$ was added the solution of proteinaceous preparation in dosages 0.01; 0.02; $0.03 \mathrm{ml}$ hypodermically. To control group in the same doses $0.9 \% \mathrm{NaCl}$ solution was given hypodermically. The sampling of blood was carried out for the 7-th, 14-th and 21-st days after introduction of the preparation. By the results of the experiment reliable increase in morphological and biochemical indicators of blood of experimental groups of laboratory animals was revealed. In the second experimental group for the 7th day of carrying out the experiment the increase in erythrocytes by $6.07 \%$, leukocytes - for $33.17 \%$, monocytes - for $86.32 \%$, lymphocytes - for $14.42 \%$ was noted. Reliable increase in biochemical indicators in this experimental group for the 7-th 
day of the experiment made: the amount of general protein - for $42.13 \%$, albumine - for $34.22 \%$, a $\alpha_{1}$ globulins - for $24.58 \%$, a $\alpha_{2}$-globulins - for $23.89 \%$ and y-globulins - for $99.18 \%$ in comparison with the data of the animals of control group. Thus specified indicators of blood remain within physiological norm.

Keywords: bone marrow preparation, laboratory animals, leukocyte formula, blood protein fractions.

Введение. Сниженное качество корма, нарушение ветеринарно-санитарных правил, ошибки в технологии содержания и прочие причины оказывают негативное влияние на резистентность организма млекопитающих и птицы, приводят к снижению уровня иммуногенности и, как следствие, прорыву иммунной защиты возбудителями, проявлению в организме инфекционных болезней [1]. Для повышения резистентности организма животных многие авторы рекомендуют использовать иммунотропные препараты [2-4]. Перспективным направлением является использование препаратов костномозгового происхождения. Действующим началом препаратов данной группы являются пептиды и биологически активные вещества, которые способны влиять на функциональную активность иммунитета [5].

Цель исследования: установить воздействие белкового препарата, полученного из клеток костного мозга крупного рогатого скота, на морфологические и биохимические показатели крови лабораторных животных.

Материалы и методы исследования. Экспериментальная часть работы осуществлялась в виварии и на кафедре ветеринарносанитарной экспертизы, эпизоотологии и микробиологии ФГБОУ ВО Дальневосточного ГАУ.

Сырьем для получения белкового препарата явился костный мозг, извлеченный из трубчатых костей крупного рогатого скота. Технология изготовления препарата включала извлечение костного мозга из трубчатых костей, суспендирование, фильтрацию, осаждение, диализ и высушивание полученного препарата. Получение препарата проводили в соответствии с рекомендациями Н.М. Мандро и Т.В. Федоренко с модернизацией метода [6].
Биологическую активность препарата изучали на лабораторных белых мышах (самцы) воз-

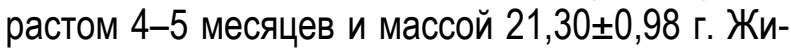
вотных распределили на 3 подопытные и 1 контрольную группы (по 21 голове в каждой). Подопытным группам однократно вводили 0,1\% раствор белкового препарата из клеток костного мозга крупного рогатого скота подкожно в дозах 0,01 мл (первая подопытная группа), 0,02 мл (вторая подопытная группа) и 0,03 мл (третья подопытная группа). Контрольной группе вводили в тех же дозах подкожно 0,9 \% раствор $\mathrm{NaCl}$. Взятие крови осуществляли методом декапитации на 7-й, 14-й и 21-й дни после введения препарата.

В крови лабораторных мышей определяли количество эритроцитов и лейкоцитов на гематологическом анализаторе Dixion HemaLite 1260. Биохимические показатели сывороток крови определяли на биохимическом анализатope Awareness technology inc. Stat fax 1904.

Полученные экспериментальные материалы подвергнуты математическому анализу методами биометрии с определением достоверности различий по t-критерию Стьюдента.

Результаты исследования и их обсуждение. Интенсивность изменения в клеточных показателях крови лабораторных животных зависела от дозы вводимого препарата (рис. 1).

Количество эритроцитов в первой опытной группе во все дни проведения опыта было достоверно увеличено на 1,60 \% по сравнению с контрольной группой. Во второй опытной группе выявлена максимальная разница с контрольной группой по сравнению с другими опытными группами - на протяжении опыта количество эритроцитов колебалось от 9,24 $\pm 0,11$ до $9,27 \pm 0,08$ 1012/л. В третьей опытной группе мышей установлено увеличение показателя к 7-му дню проведения эксперимента на $3,32 \%$, затем происходило постепенное снижение количества эритроцитов до 2,18 \% к 21-му дню по сравнению с контрольными данными.

Уровень лейкоцитов в первой опытной группе по сравнению с контрольной на 7-й день исследования увеличился на 9,23 \%, к 21-му дню - на $8,20 \%$. Во второй опытной группе животных увеличение показателя по сравнению с контрольными данными составило 33,17 \%, максимум повышения установлен на 14-й день (34,06 \%). 
В третьей опытной группе максимальный показатель отмечен в 21-й день и составил $8,10 \pm 0,14$ 10\% ת.
При изучении лейкограммы опытных мышей нами выявлены определенные закономерности (рис. 2).

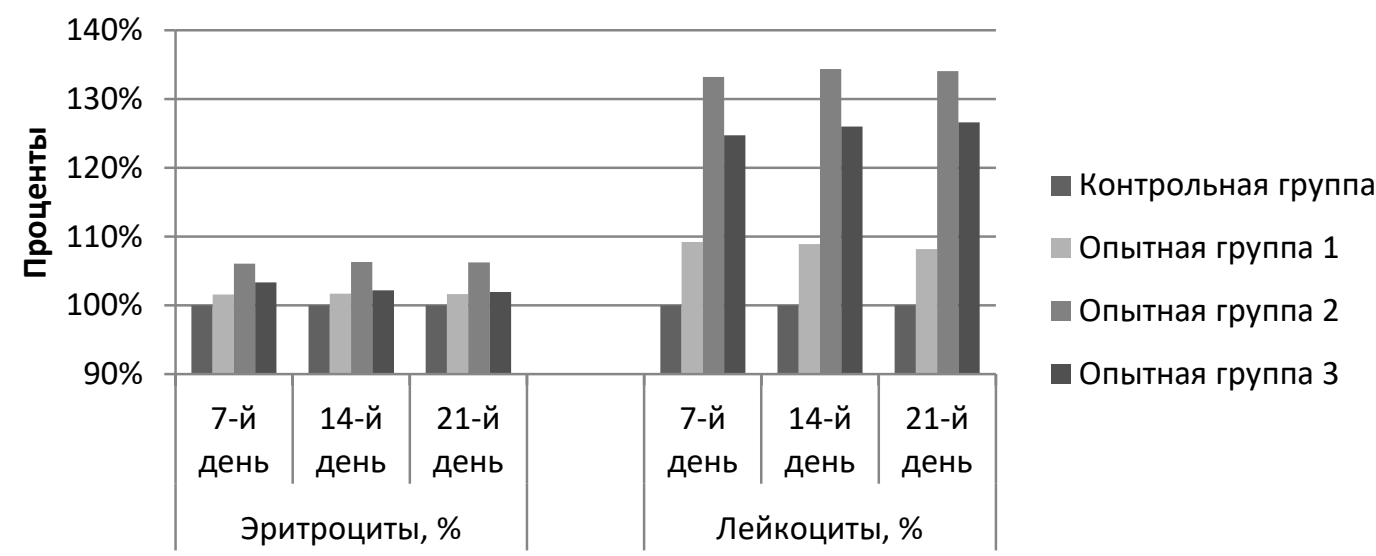

Puc. 1. Динамика изменения содержания эритроцитов и лейкоцитов крови лабораторных мышей при использовании белкового препарата костномозгового происхождения, $n=84$

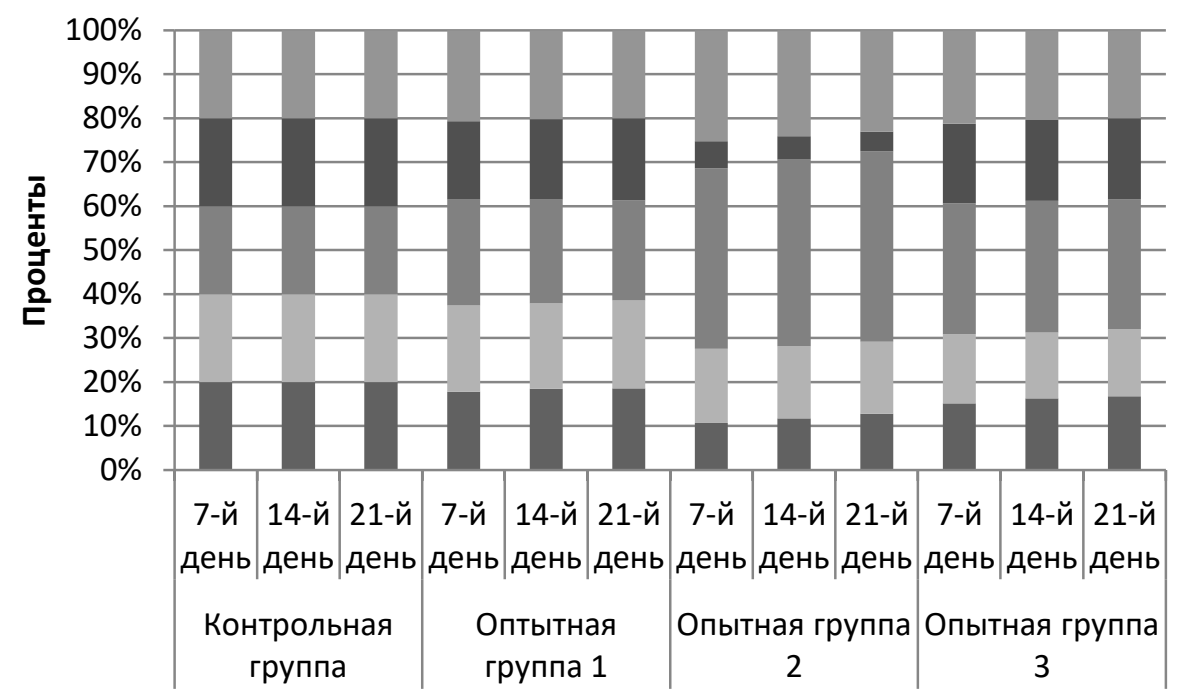

пимфоциты, \%

• Эозинофилы, \%

Моноциты, \%

Сегментоядерные нейтрофилы, \%

- Палочкоядерные нейтрофилы, \%

Puс. 2. Динамика изменения лейкоцитарной формулы крови лабораторных мышей при использовании белкового препарата костномозгового происхождения, \%, $n=84$

Изменения количества палочкоядерных нейтрофилов выявлены во всех опытных группах уже на 7-й день исследования. В первой опытной группе по сравнению с фоновыми данными уровень палочкоядерных нейтрофилов уменьшился на 11,97 \%; во второй - на 51,29; в третьей - на 22,80 \%. К 21-му дню процент изменения во всех опытных группах уменьшался, приближаясь к показателям контрольной группы.
В первой опытной группе на 7-й день исследования показатели сегментоядерных нейтрофилов снизились на $3,40 \%$; во второй - на 23,43; в третьей - на 20,31 \%. Данная тенденция сохранялась и в последующие дни, демонстрируя незначительное увеличение показателя ко времени завершения опыта.

Показатель количества моноцитов наиболее сильно достоверно увеличился во второй опытной 
группе по сравнению с фоновыми показателями: на 7-е сутки увеличение составило 86,32 \%; на 14-е - 100,50; на 21-е - 110,00\%. Во второй опытной группе максимум повышения установлен на 14-й день исследования и составил 57,50 \% по сравнению с контрольной, в первой - 18,39 \% на 7-й день эксперимента.

Достоверное уменьшение показателя количества эозиносилов отмечено во всех подопытных группах. Во второй опытной группе выявлено уменьшение данного показателя на 78,30 \% на 21-й день эксперимента по сравнению с фоновыми показателями. В первой опытной группе достоверное уменьшение составило $12,15 \%$ на 7-й день проведения с последующим стремлением к показателям контрольной группы. Третья опытная группа продемонстрировала аналогичный результат, ее показатель уменьшения составил 8,32 \% на 7-й день исследования.

Количество лимфоцитов в первой опытной группе в процентном отношении к контрольным данным показало увеличение на 2,27 \% на 7-й день эксперимента с последующим уменьшением разницы к 21-му дню. Во второй опытной группе на 7-й день показатель увеличился на $14,42 \%$, в третьей - на 8,14 \% по сравнению с фоновыми значениями, выявлена тенденция к постепенному снижению количества лейкоцитов к 21 -му дню эксперимента.

При исследовании содержания общего белка и белковых фрракций в сыворотке крови исследуемых животных отмечены следующие изменения. Во всех опытных группах по сравнению с контрольной на протяжении эксперимента показатели общего белка стабильно достоверно повышаются (рис. 3).

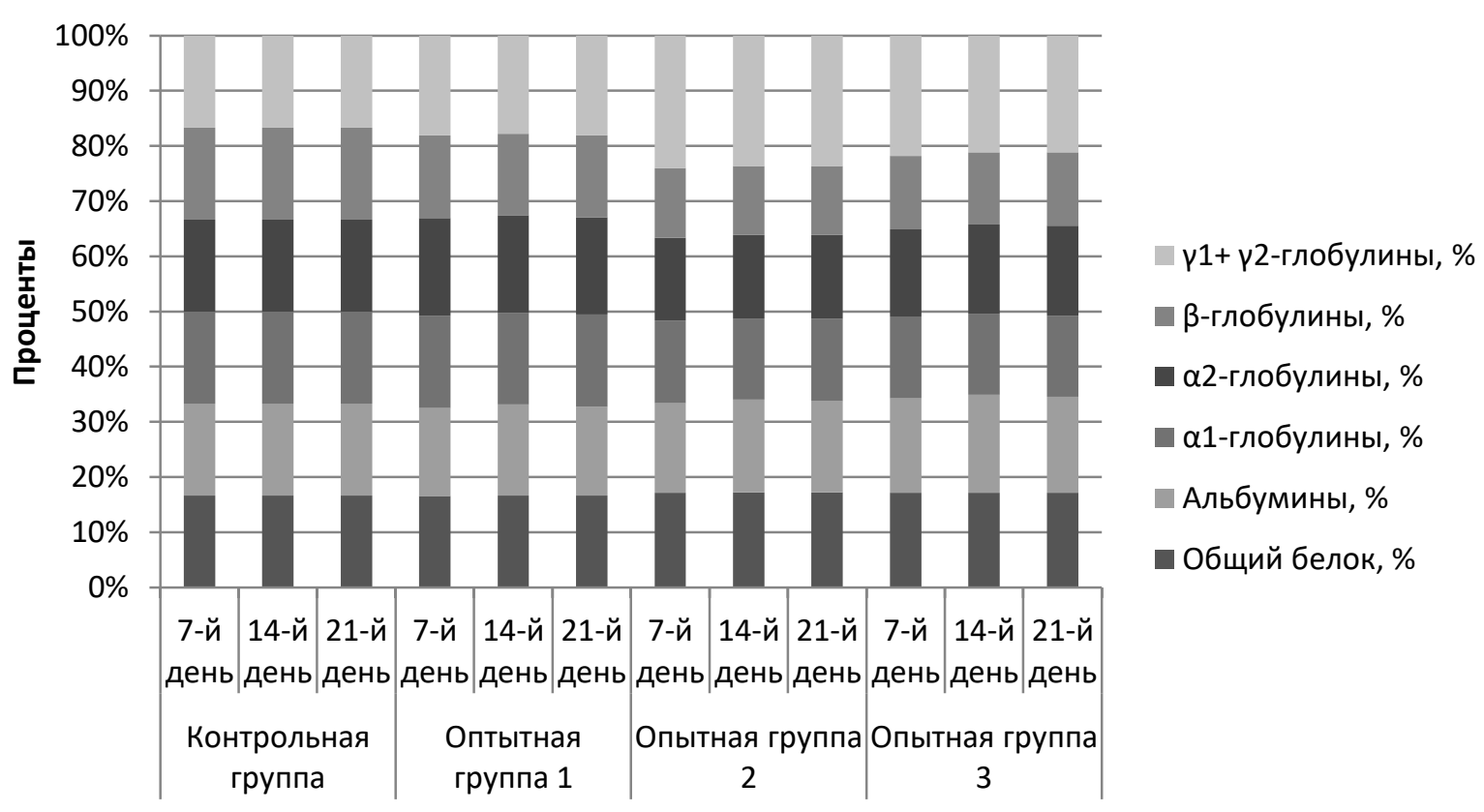

Pис. 3. Биохимические показатели крови белых мышей после введения препарата из костного мозга крупного рогатого скота, $n=84$

В первой опытной группе достоверное увеличение общего белка составило 13,12\% по сравнению с контрольными показателями; во второй - 42,86; в третьей - 32,70\%.

Во всех опытных группах максимальное количество альбуминов отмечено на 14-е сутки исследования, достоверное увеличение в первой опытной группе по сравнению с контроль- ными показателями составило 12,86 \%; во второй - 38,70; в третьей - 37,16 \%.

Показатель $a_{1}$-глобулинов в первой группе лабораторных животных увеличился на 14,38 \%; во второй - на 24,58; в третьей - на 15,22 \% по сравнению с данными контрольной группы. Показатель стабилен во все дни исследования.

Содержание $a_{2}$-глобулинов продемонстрировало достоверное увеличение на 7-й день экспе- 
римента - в первой опытной группе на 20,67 \% по сравнению с контрольной; во второй - на 23,89 ; в третьей - на 22,28\%. Тенденция сохранилась и на 21-й день, показатель по сравнению с 7-м днем незначительно увеличился во всех опытных группах.

Достоверное увеличение содержания $\beta$ глобулинов в сыворотке крови в первой опытной группе составило 2,59\%; во второй - 4,86; в третьей - 3,00 \% на 7-й день проведения эксперимента.

Сумма показателей ү1- и ү2-глобулинов во второй исследуемой группе по сравнению с контрольной увеличилась на 99,18 \% в первую неделю эксперимента, в первой группе на 7-й день увеличение составило $23,40 \%$, в третьей $69,09 \%$.

Заключение. Таким образом, выявлено достоверное увеличение морфологических и биохимических показателей крови лабораторных животных при воздействии препарата из клеток костного мозга крупного рогатого скота. На 7-й день проведения эксперимента отмечено достоверное увеличение эритроцитов во второй опытной группе на $6,07 \%$; лейкоцитов - на 33,17 ; моноцитов - на 86,32; лимфоцитов - на 14,42 ; общего белка - на 42,13; альбуминов - на 34,$22 ; a_{1}$-глобулинов - на 24,58; $\alpha_{2}$-глобулинов на 23,89 и ү-глобулинов на 99,18 \% по сравнению с контрольными показателями. При этом указанные показатели крови остаются в пределах фризиологической нормы.

\section{Литература}

1. Камалиева М.Г., Асрутдинова Р.А., Гарипов С.М. Влияние условий содержания ремонтного молодняка кур на формирование иммунитета и качество мяса // Вестн. КрасГАУ. - 2017. - № 5. - С. 35-39.

2. Petrov R.V., Mikhailova A.A., Fonina L.A. Bone marrow immunoregulatory peptides (myelopeptides): structure, function, mechanism of action // Immunology Letters. Vol. 56, P. 1. - May 1997, p. 165-166.

3. Гришко В.А., Малина В.В., Балацкий Ю.А., Лясота В.П. и др. Влияние иммуностимуляторов на основе тимуса и костного мозга на гормональный фон поросят-сосунов //
Вестн. Брянской ГСХА. - 2017. - № 1 (59). C. 7-13.

4. Тютрина С.Ф., Безбородов Н.В. Содержание липидов в крови коров при стимуляции воспроизводительной функции биорегуляторными пептидами // Изв. ОГАУ. - 2016. № 3 (59). - C. 106-108.

5. Мандро Н.М., Федоренко Т.В. Костный мозг, его состав и структура в сравнении у диких жвачных и сельскохозяйственных // Вестн. КрасГАУ. - 2013. - № 5. - С. 181184.

6. Мандро Н.М., Федоренко Т.В. Рекомендации по применению белкового препарата из клеток костного мозга. - Благовещенск: Изд-во Дальневосточного ГАУ, 2016. - 24 с.

\section{Literatura}

1. Kamalieva M.G., Asrutdinova R.A., Garipov S.M. Vliyanie uslovij soderzhaniya remontnogo molodnyaka kur na formirovanie immuniteta i kachestvo myasa // Vestn. KrasGAU. - 2017. № 5. - S. 35-39.

2. Petrov R.V., Mikhailova A.A., Fonina L.A. Bone marrow immunoregulatory peptides (myelopeptides): structure, function, mechanism of action // Immunology Letters. Vol. 56, P. 1. - May 1997, p. 165-166.

3. Grishko V.A., Malina V.V., Balackij Yu.A., Lyasota V.P. i dr. Vliyanie immunostimulyatorov na osnove timusa i kostnogo mozga na gormonal'nyj fon porosyat-sosunov // Vestn. Bryanskoj GSKHA. - 2017. - № 1 (59). S. 7-13.

4. Tyutrina S.F., Bezborodov N.V. Soderzhanie lipidov $v$ krovi korov pri stimulyacii vosproizvoditel'noj funkcii bioregulyatornymi peptidami // Izv. OGAU. - 2016. - № 3 (59). S. 106-108.

5. Mandro N.M., Fedorenko T.V. Kostnyj mozg, ego sostav i struktura $v$ sravnenii $u$ dikih zhvachnyh i sel'skohozyajstvennyh // Vestn. KrasGAU. - 2013. - № 5. - S. 181-184.

6. Mandro N.M., Fedorenko T.V. Rekomendacii po primeneniyu belkovogo preparata iz kletok kostnogo mozga. - Blagoveshchensk: Izd-vo Dal'nevostochnogo GAU, 2016. - 24 s. 